\title{
The Influence of Relational Learning of a Transnational Egocentric Network on Innovation Competence for Internationalization
}

\author{
Alex Sandro Quadros Weymer ${ }^{1}$, Heitor Takashi Kato ${ }^{2}$, Claudimar Pereira da Veiga ${ }^{2,3}$ \& Alex Antônio Ferraresi ${ }^{1}$ \\ ${ }^{1}$ Graduate Program in Cooperative Management (PPGCOOP) at Pontifícia Universidade Católica do Paraná \\ (PUCPR), Imaculada Conceição street, 1155, Zip code 80215-901, Curitiba, PR, Brazil \\ ${ }^{2}$ Business School Postgraduate Program (PPAD), Pontifícia Universidade Católica do Paraná (PUCPR), \\ Imaculada Conceição street, 1155, Zip code 80215-901, Curitiba, PR, Brazil \\ ${ }^{3}$ Business Management Graduate Program (DAGA), Department of General and Applied Administration, \\ Federal Universidade Federal do Paraná (UFPR), 632 Lothário Meissner Ave, Jardim Botânico, Zip code \\ 80210-170, Curitiba, PR, Brazil \\ *Corresponding author. Correspondence: Claudimar Pereira da Veiga, Business School Postgraduate Program \\ (PPAD), Pontifícia Universidade Católica do Paraná (PUCPR), Imaculada Conceição street, 1155, Zip code \\ 80215-901, Curitiba, PR, Brazil. Tel: 55-41(41)3271-1329. E-mail: claudimar.veiga@gmail.com, \\ alex.weymer@pucpr.br
}

Received: April 16, 2017

doi:10.5539/mas.v11n7p38
Accepted: May 17, 2017

Online Published: June 9, 2017

URL: https://doi.org/10.5539/mas.v11n7p38

\begin{abstract}
The purpose of this article is to evaluate the influence of a transnational egocentric network on the innovation competence for internationalization for a transnational focal organization — considered one of the main players in the telecommunications sector worldwide. The theoretical-empirical framework relies on the perspectives of innovation, relational learning, and relational embeddedness in inter-organizational networks. With regard to methodology, the design chosen for this research was data collection, since it deals with relational data treated dyadically, using the network analysis technique to identify the egocentric network configuration with the use of UCINET software. We conclude that the studied network is oriented toward innovation and the analyzed variables show a high degree of complexity, especially in relation to the wide-reaching treatment of innovation as overlapping with the traditional indicators and with an emphasis on technology or research and development. In this sense, the main contribution of this research is to show that the traditional conception of organizational competence as an internal resource can be extended to the perspective of relational embeddedness by considering innovation for internationalization as an inter-organizational level of competence, creating the need to undertake new studies that will complement the explanatory power, in addition to the learning dimensions, that are contemplated in this research.
\end{abstract}

Keywords: Innovation, Learning in network, Internationalization, Relational embeddedness, Telecommunication Sector

\section{Introduction}

The telecommunications sector is not only affected by constant global transformation, but also plays a strategic role by significantly influencing other sectors of the economy (Rauen, Hiratuka \& Fracalanza, 2011; Symeou, 2011). Telecommunications services have become a determining factor in a complex and connected milieu, with a strong transformative effect on society, especially with the advent of the Internet (Nishijima, Ivanauskas, \& Sarti, 2017). According to Ohmae (2006), the Internet seems to be the best evidence of a world with much less restrictive national borders than in the past.

Traditional conceptions of services are altered as they incorporate new services and integrate others into the medium of telecommunication. Such transformations require a constant process of innovation by companies that operate in the field, both in the linear perspective with a focus on processes of production and scientific research, as well as in the non-linear perspective, conceiving innovation as a complex process of interaction and learning (Freire, Baldi \& Lopes, 2010), which is the main interest of this study.

The relevance of learning in a global context is justified by the ability and willingness of transnational 
companies to learn and adapt from the varying realities of a given market. This adaptation is particularly complex for large companies, because they have more formal internal processes and, consequently, it is difficult for them to reconcile different aspects of the structural, resource, and management spheres (Symeou, 2011).

In this scenario characterized by change and strong competition, innovation, as well as learning, has also occupied an important space in business discussions, gaining evidence in academic research in the last 30 years for its relevance in the context of world transformations, especially in terms of global economic integration, holding a prominent position, and as a key factor for economic growth (Chetty \& Stangl, 2010; Ruem et al., 2011).

It is important to emphasize that innovation, from an analytical and comprehensive perspective, transcends usual indicators, which prioritize the focus on research and development and support the linear argument that research leads to the commercialization of new technologies (Marins \& Zawislak, 2010; Veiga et al., 2016). On the other hand, when innovation is seen as a complex and multidimensional process, this implies the recognition of the need to combine three important research elements: internationalization, innovation, and networks (Chetty \& Stangl, 2010; Wu et al., 2016).

Based on the above findings, the aim of this study is to assess the influence of an egocentric transnational network on the ability of a transnational focal organization, considered one of the leading global players in the telecommunications industry, to innovate and internationalize. In addition to the focal organization, the network includes 18 companies that are considered strategic and fundamental for the development of its activities, indicated based on the snowballing technique (Biernacki \& Waldorf, 1981). The network configuration was structured based on the Weymer et al. (2017).

The aim of this study is to relate perspectives recognized in the literature and to fill the gap in existing studies, using new theoretical approaches that have empirical support from experiments conducted in social sciences. In this sense, the present study assumes that there is a congruence between the innovation competence of global companies and inter-organizational learning, and that the concept of organizational competence as an internal resource can be extended to the perspective of relational embeddedness when considering innovation for internationalization as a competence at the inter-organizational level.

This paper is divided into five sections. After a brief introduction, which includes the objective of the study, we focus on the theoretical basis related to innovation, relational learning, and relational embeddedness in inter-organizational networks. Thereafter, the methodological and analytical procedures that underpinned the data analysis are presented. Then, the results of the research are discussed; lastly, final considerations are presented.

\section{Literatue Review}

\subsection{Innovation}

Innovation, as a complex process, requires an analytical and comprehensive understanding that transcends the intra-organizational dimension and exclusive focus on technology or research and development. Chetty and Stangl (2010), for example, argue that innovation is a multidimensional process that essentially involves novelty, and they highlight the need to combine three important research elements: internationalization, innovation, and networks (Wu et al., 2016)

An important theoretical essay from the perspective of innovation networks is presented by Freire, Baldi, and Lopes (2010), based on the congruence of the social networks approach, notably regarding social ties (Granovetter, 1973) and innovation networks (Hage \& Hollingsworth, 2000).

This essay stimulated studies with a more comprehensive analytical dimension, in which the innovation process moves from internal to collective construction, through inter-organizational relations at local, national, or global levels. The approach of innovation networks has focused on creating radical innovations of products and processes at a transnational level, which is justified by the growing need to understand and promote processes of innovation as a way of entry and survival for organizations in globally competitive networks, which are configurated as forms of governance in new patterns of inter-organizational relations.

Traditional indicators of innovation—among which are, notably, research and development statistics and patents - rely on the linear argument that research leads to the commercialization of new technologies, which results in the belief that, currently, Latin American firms are limited to performing passively in global activities of innovation (Marins \& Zawislak, 2010).

Lawson and Samson (2001) conducted an extensive review of the literature on innovative management, along 
with a case study of Cisco Systems. They suggest a conceptual framework related to this issue, with significant influence of Kanter's work (1989). This model argues that substantial investment in innovation competence may be the main driver for wealth creation, rather than physical asset ownership. The dependent variable "innovation competence for internationalization" of this study is supported.

Additionally, according to Lawson and Samson (2001), despite the uncertainty inherent to the issue of innovation, there are underlying patterns that can be identified. In this sense, based on the literature on dynamic capabilities, the proposal of a holistic model of innovation competence within the company-in the terms defined by the authors - is composed of seven elements: vision and strategy, harnessing the competence base, organizational intelligence, creativity and idea management, organizational structure and systems, culture and climate, and management of technology, as illustrated in Fig. 1.

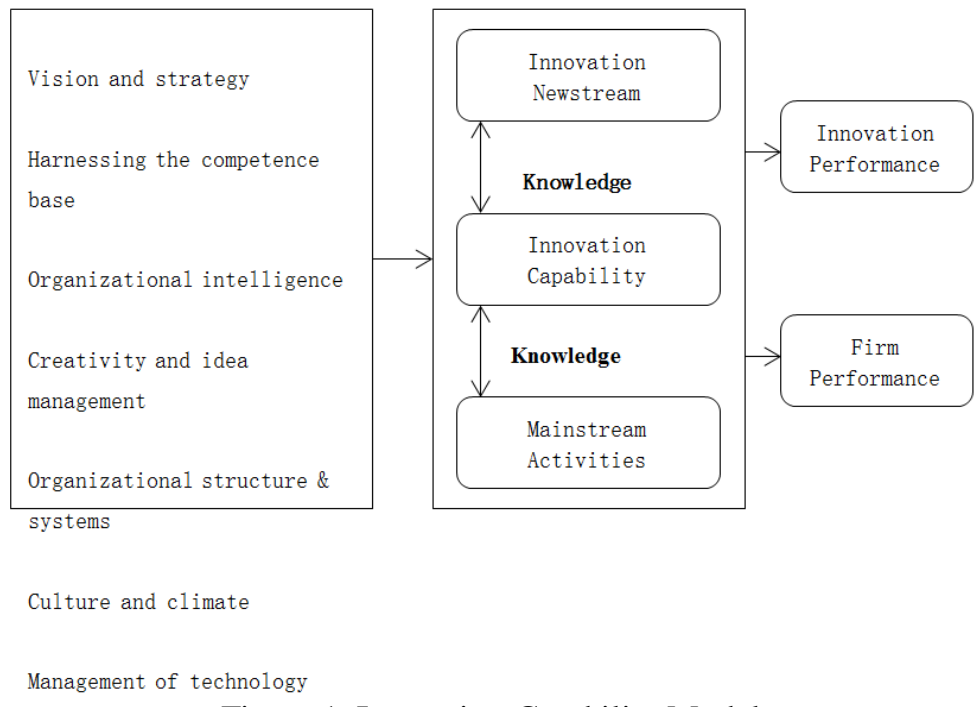

Figure 1. Innovation Capability Model

Source: Lawson and Samson (2001, p.388).

Kanter (1989) argues that the effective management of two streams (mainstream and newstream) helps organizations to balance the pressure of stability and change. The main activities (mainstream) provide funding for the development of new flows (newstream). Thus, new products and processes are assimilated back into the mainstream through ongoing development activities (i.e., doing the same things in a better way) that arise from the constant communication between the two streams.

\subsection{Relational Learning}

There is a great need to expand cross-cultural research to deepen the understanding of the value of collaboration across domestic boundaries. Dyadic relationships should be considered, which could help draw relevant conclusions and provide significant insights to contribute to this understanding (Hillman, 2009). Cheung, Myers, and Mentzer (2011) define relational learning as a joint activity between a supplier and a buyer in which the two parties share information, which is interpreted and integrated into a shared memory that alters the probability of a specific behavior in the contractual relationship.

These relationships vary in terms of potential for learning, and can generate improvement in performance and relationships, because they develop appropriate mechanisms for learning (Selnes \& Sallis, 2003). However, a number of issues remain to be addressed. The complexity and dynamic nature of "cross-border" knowledge flows present major challenges in coordinating and translating learning to the advantage of a particular firm.

In relation to inter-organizational exchanges, certain firms have capabilities that allow them to excel in their markets through related combinations (e.g., dyads). Dyadic relationships are defined as "the systematic strategic coordination of traditional business functions and tactics through these business functions within a particular firm and through business [...] for the purpose of improving long-term performance of individual companies and of the supply chain as a whole” (Mentzer, Min \& Zacharia, 2000, p. 550).

According to Chung and Yeaple (2008), research related to relational learning between organizations has found strong links to business performance and competitive advantage. Selnes and Sallis (2003) conceptualize 
relational learning as a joint activity in which the two parties strive to create more value together than they could create individually or with other partners. It is believed that the capability of a relationship for learning is closely linked to the way it is managed and the context in which it is incorporated (Pinho \& Prange, 2016).

The concept of relational learning proposed by Cheung, Myers, and Mentzer (2011) is consistent with the interaction perspective of Hakansson and Snehota (1995), which suggests that two firms affect and are affected by each other in a relatively longer period. In this sense, the authors consider relational learning as a multidimensional construct consisting of information sharing, joint sensemaking, and knowledge integration. Table 1 presents the definitions based on the article by Cheung, Myers, and Mentzer (2011), which helps to adequately understand the methodological aspects of this research.

Table 1. Relational learning as a multidimensional construct

\begin{tabular}{l|l}
\hline Variable & Definition \\
\hline Information & $\begin{array}{l}\text { Exchange of information with the related company regarding the following factors: } \\
\text { experiences about the products exchanged in the relationship; changes in needs, preferences, } \\
\text { and behavior of the end user; changes in market structure, such as mergers, acquisitions, or } \\
\text { partnerships; changes in the technology of main products; unexpected problems; changes in the } \\
\text { strategies and policies of both companies; finance, performance, and know-how. } \\
\text { Congruence in construction of meaning (joint sensemaking) with the other company on the } \\
\text { following factors: creation of joint teams to solve operational problems in the } \\
\text { relationship; creation of joint teams to analyze and discuss strategic issues; productive } \\
\text { discussion that includes a variety of opinions stimulated by a favorable climate between } \\
\text { Sensemaking }\end{array}$ \\
$\begin{array}{l}\text { companies; direct communication. } \\
\text { Evaluation of and adjustment to, when necessary, the following situations when relating to the } \\
\text { other company: needs and behaviors of the end user; technologies related to its } \\
\text { Integration } \\
\text { business; routines in order to organize processes; formal contracts in the relationship; personal } \\
\text { encounters to "refresh" the personal side of the relationship; information about the relationship, } \\
\text { storedin electronic databases; contribution to innovationin the company's products. }\end{array}$ \\
\hline
\end{tabular}

Source: Adapted from Cheung, Myers, and Mentzer (2011)

\subsection{Relational Embeddedness in Inter-Organizational Networks}

The understanding of how behaviors and institutions are affected by social relations is critical from the perspective of social theory. According to Granovetter (1985), the concept of embeddedness refers to the fact that behaviors and institutions are constrained by continuous social relations, and therefore, should not be analyzed independently. Although the aforementioned study focuses on economic behavior, the author argues that this perspective applies to all behaviors.

Applied to the context of multinational corporations, relational embeddedness refers to the extent to which each subsidiary, from relationships with customers, suppliers, competitors, and other actors, can serve as a source of learning. An underlying idea is that actors who are strongly linked are better able to exchange information, and thus, learn more from the relationship (Uzzi, 1996; Hansen, 1999; Kueny et al., 2017).

An important distinction of this research is the emphasis on relational and structural embeddedness. While in relational embeddedness, the analytic approach relates to dyads (pairs), structural embeddedness related to multinational corporations highlights the advantage that a subsidiary can have from its position in the network rather than the advantage from information obtained through the exchange in individual relationships (Granovetter, 1992; Gulati, 1998).

Although the concept of network embeddedness has been discussed in a wide variety of studies with varying views, it is possible to identify some lines of convergence. First, network embeddedness can be seen as a strategic resource that can influence the firm's future capability and expected performance (Andersson, Forsgren \& Holm 2002), and therefore, performance may vary across firms due to differences in the degree of embeddedness in the network. Second, embeddedness in business networks allows for relationships based on adaptation and trust developed over time. Consequently, embeddedness should be treated as a variable on a continuum and not as a dichotomy that is either missing or present. Third, most studies recognize embeddedness as a strategic resource, both in the relational and structural dimensions. 


\section{Methodological Procedures}

To achieve the aim of this research, the network analysis technique was used to identify the configuration of the egocentric network using UCINET software. Such a configuration propitiated the identification of eight independent variables, including the centrality measures (degree, closeness, betweenness, eigenvector), the measure of structural holes (effsize), and inter-organizational learning regarding information sharing, joint sensemaking, and knowledge integration dimensions, as contemplated in the theoretical framework. The definitions of measures of centrality and structural holes, based on articles by Wasserman and Faust (1994), Scott (2000), and Burt (1995), can be seen in the Table 2.

Table 2. Definitions of measures of centrality and structural holes

\begin{tabular}{l|l}
\hline Variable & Definition \\
\hline Degree & $\begin{array}{l}\text { Centrality of degree, which is measured by number of connections that an actor has } \\
\text { established. In this study, connections were treated as symmetric, that is, reciprocal relations. } \\
\text { Centrality of proximity, which considers the minimum number of steps that an actor needs to } \\
\text { establish contact with other actors in the network. } \\
\text { Betweenness } \\
\text { Centrality of intermediation, which emphasizes those actors that serve as connection links } \\
\text { between actors in the network, and can influence the structure of the network. } \\
\text { Centrality measure that allows for identification of the degree of centrality of each actor in the } \\
\text { network, and may be related to the level of prestige. } \\
\text { Eeffsize }\end{array}$ \\
\hline
\end{tabular}

Source: Adapted of the Wasserman and Faust (1994); Brut (1995) and Scott (2000).

For the analysis of "innovation competence for internationalization," SPSS software was used to identify and verify the congruence of the seven elements, resulting in seven factors that, after the non-parametric correlation, served to help establish the relationship between the independent and dependent variables.

One of the difficulties in working with network analysis is the definition of network boundaries and, consequently, structure configuration, especially when the research is considering the network as a whole as the focus of analysis (full network design). Concerning egocentric networks, the boundaries are defined during data collection, through the name generation technique (MARSDEN, 2005), or, in the case of this study, from the naming of organizations by a focal organization. According to Wasserman and Faust (1994), an egocentric network consists of a focal actor, called the ego, and a set of other actors who have ties with the ego, as well as measurements of the bonds between these actors.

\subsection{Research Characterization}

The research design of this study is survey, as it contemplated agents of 19 (nineteen) organizations, providing 342 possibilities of relationships, considering the dyadic relations. The details of the network configuration on issues of centrality, density and structural equivalence can be seen in Weymer et al. (2017).

According to Scott (2000), although there are different types of data (see Figure. 2), each with its own method of analysis, they are often collected as integral aspects of the same research.

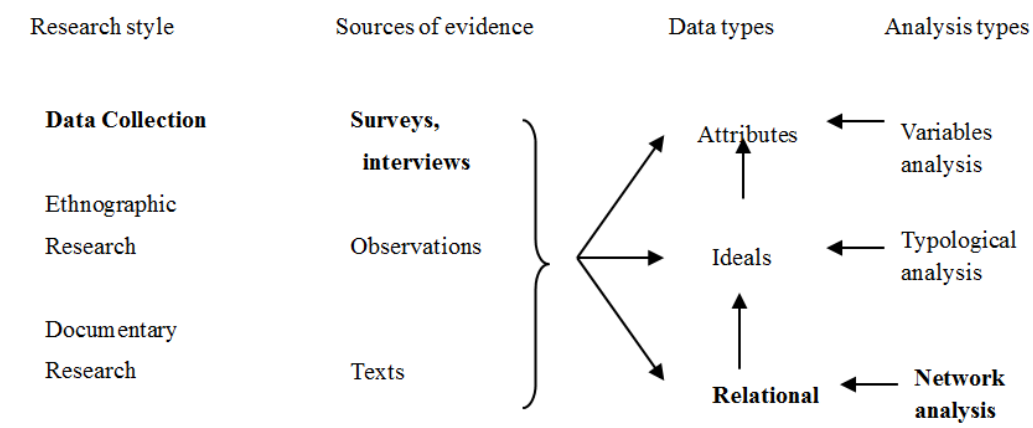

Figure 2. Types of data and analysis

Source: Scott (2000, p.3) 


\subsection{Population and Sample}

Among the 19 companies surveyed, eight are other subsidiaries located in six different countries: Argentina, Singapore, Colombia, Mexico, China, and Brazil, with two São Paulo subsidiaries (one with an emphasis on development), and one from Rio de Janeiro, as well as the Curitiba subsidiary, which is considered the focal company. Another country that is part of the network is Germany, which although is not the headquarters of the joint venture, was considered to be in the network as a parent company because it owns half of the shares resulting from the merger between companies (Weymer et al. 2017).

All organizations in the network operate internationally, with the participation of 10 different countries, including Brazil. Considering that contact with the majority of companies was carried out in English, it was decided that the terminologies and acronyms used in the analysis of the network configuration should be presented in the same language. The network also consists of two categories of organizations: five suppliers and four logistics partners, with headquarters in different countries, such as France, the USA, Switzerland, Colombia, Slovenia, and Brazil.

\subsection{Data Collection and Analysis}

In the first stage of the research, three professionals, considered gatekeepers, were identified and interviewed, in order to understand the scenario in which the company is inserted and its strategic positioning at a global level. During the interview, they named the first organizations that they considered fundamental for the process of innovation and their activities, which generated other contacts that were also contacted. They named other organizations, totaling 19 players in the network, including the Curitiba/Brazil subsidiary.

The second stage was the definition of the configuration of the network of relationships. For this purpose, a survey was applied which resulted in structured data in a matrix. According to Scott (2000), a data matrix is a table of figures organized in rows and columns with incidental or adjacent relations. From these data, it was possible to identify measures of centrality and structural holes, as well as inter-organizational learning in the following dimensions, which are considered as the independent variables: information sharing, joint sensemaking, and knowledge integration. Considering that all companies in the network are transnational and eight of the respondents are located in other countries, the survey was translated into English and sent by e-mail, with frequent follow-up through telephone contact.

In the third stage, the characteristics of innovation competence were identified through the application of a survey, based on the seven elements for innovation competence as proposed by Lawson and Samson (2001), for each of the companies that are part of the relationship network.

In order to consider these data, it was necessary to first analyze the data of the dependent variable "innovation competence for internationalization," which were obtained through a survey with 39 variables, divided into seven elements. The degree of reliability of the set of variables was then identified to justify the seven factors, which were used for non-parametric correlation analysis. This allowed for identification of the degree to which the egocentric network is directed toward innovation competence for internationalization. In addition to the independent variables, density, structural equivalence, and structural holes measurements were also identified, thus providing support for the analysis.

Thereafter, the Euclidean distance was calculated for each of the independent variables and the dependent variable, which was necessary to standardize the scores of the variables analyzed. This allowed for a comparison between them, without affecting the results regarding the measurement scale and the number of variables that were used to calculate the difference, as proposed by Mandy (2008). Multiple Regression via Quadratic Assignment Procedure (MRQAP) was used to identify the relationship between inter-organizational learning and innovation competence for internationalization in the network of relationships.

\section{Presentation and Data Analysis}

Data analysis is structured as follows: 1) the first part consists of an analysis of the dependent variable, called the innovation competence for internationalization, which is composed of 39 indicators divided into seven dimensions (factors). It was decided that the seven factors should be merged into a single global measure by joining the mean of these factors; 2) the second analysis consists of the configuration of the network based on centrality, core/periphery, structural equivalence, and the identification of five independent variables obtained from the symmetrical network - Degree, Closeness, Betweenness, and Eigenvector, which are standard measures of centrality, as well as Effsize, which is a measure of structural holes.The three dimensions of organizational learning—information sharing, joint sensemaking, and knowledge integration—are considered the main independent variables; 3) in the third part, MRQAP was performed to identify the relationship between 
inter-organizational learning and the innovation competence for internationalization in the relationship network. UCINET software supported both steps 2 and 3 of the analysis.

The data for the analysis of the dependent variable "innovation competence for internationalization" were obtained through a questionnaire with 39 variables, divided into seven elements that contribute to a firm's performance, according to Lawson and Samson (2001): vision and strategy, harnessing the competence base, organizational intelligence, creativity and idea management, organizational structure and systems, culture and climate, and management of technology. For each of the indicators, the respondent had the option to indicate on a scale of 1 to 10 how much he or she agreed with the statements made about the elements related to the "Innovation Competence for Internationalization” of his company, from "1: Totally Disagree”; "10: Totally Agree.”

Although the number of 19 companies seems insignificant for statistical inferences, it is quite expressive when the chosen technique for data analysis is network analysis. According to Reinert and Maciel (2012), as the traditional multiple regression tests assume independence between observations, it was necessary to find alternatives to resolve the frequent violation of this assumption in the dyads analysis. The Quadratic Assignment Procedure (QAP) technique was found to be the most suitable procedure for network analysis and analysis of similarity between behaviors. This technique uses the Ordinary Least Squares (OLS) method, but adjusts the individual coefficient by the probability that it is greater or lesser than the coefficient that would occur at random.

According to Hair et al. (2009, p. 155), "the reference predictor used in regression is the simple mean of the dependent variable, which has several desirable properties [...]." Thus, the use of this measure in this analysis is justified. In this sense, it was possible to define the construct of the dependent variable "innovation competence for internationalization" from the average of the seven factors. Considering the 19 companies of the network of relationships, the overall mean of 7.62 indicates that the egocentric network is innovation oriented, as shown in Table 3.

Table 3. Overall mean of the dependent variable factors

\begin{tabular}{l|l}
\hline Companies in the Network & DV mean \\
\hline 1. Subsidiary_Argentine & 6.30 \\
2. Subsidiary_Singapore & 5.43 \\
3. Subsidiary_Colombia & 8.46 \\
4. Subsidiary_Mexico & 5.64 \\
5. Headoffice_Germany & 6.97 \\
6. Subsidiary_China & 8.63 \\
7. Subsidiary_Brazil_CWB & 8.35 \\
8 Subsidiary_Brazil_RJ & 6.33 \\
9. Subsidiary_Brazil_SP & 7.72 \\
10. Subsidiary_Brazil_Academy & 7.28 \\
11. Supplier 1(Matrix: Brazil) & 8.60 \\
12. Supplier 2 (Headquarters: Brazil) & 8.82 \\
13. Logistic Partner 1 (Matrix: Switzerland) & 7.43 \\
14. Logistic Partner 2 (Matrix: Switzerland) & 8.25 \\
15. Logistic Partner 3 (Matrix: USA) & 8.93 \\
16. Supplier 3 (Matrix: Colombia) & 7.49 \\
17. Supplier 4 (Matrix: Brazil) & 7.09 \\
18. Logistic Partner 4 (Headquarters: France) & 8.07 \\
19. Supplier 5 (Matrix: Slovenia) & 9.08 \\
Overall mean & $\mathbf{7 . 6 2}$ \\
\hline
\end{tabular}

Source: Research data

\subsection{Network Configuration And Independent Variables}

The study on networks can be analyzed from a perspective of their structural or morphological characteristics, and can be treated comprehensively, either by considering the totality of the network or by separating the specific connections between actors, according to the researcher's interest, as is the case of pairs analyses (dyads) 
in this study. Such characteristics are fundamental in achieving the aim of this research, as in addition to providing a general overview of the network based on density, centrality, equivalences, and structural holes, some characteristics are used as independent variables along with the dimension of inter-organizational learning.

The analysis of social networks used in this study is characterized as a method because it is not characterized as a research strategy (e.g., a survey, ethnography, or case study), but rather as a set of techniques employed specifically in the treatment of relational data (variables of ties between social actors) of different levels, since these techniques can be used in several research designs (Reinert \& Maciel, 2012).

The subsequent analysis treated the network symmetrically, that is, without considering the directional differences in the relationships. Considering that the interest of this research is to identify flows that arise from relationships, regardless of reciprocity, the "degree" satisfies this need, as it indicates the number of direct relationships between actors (in this case, organizations of the network), as well as one of the elements for calculating centrality (Borgatti, Everett \& Freeman, 2002). The network of relationships among the 19 organizations of the egocentric network, which originated from the organization S_CWB (a subsidiary in Curitiba, Paraná, Brazil), can be illustrated as follows in Figure 3:

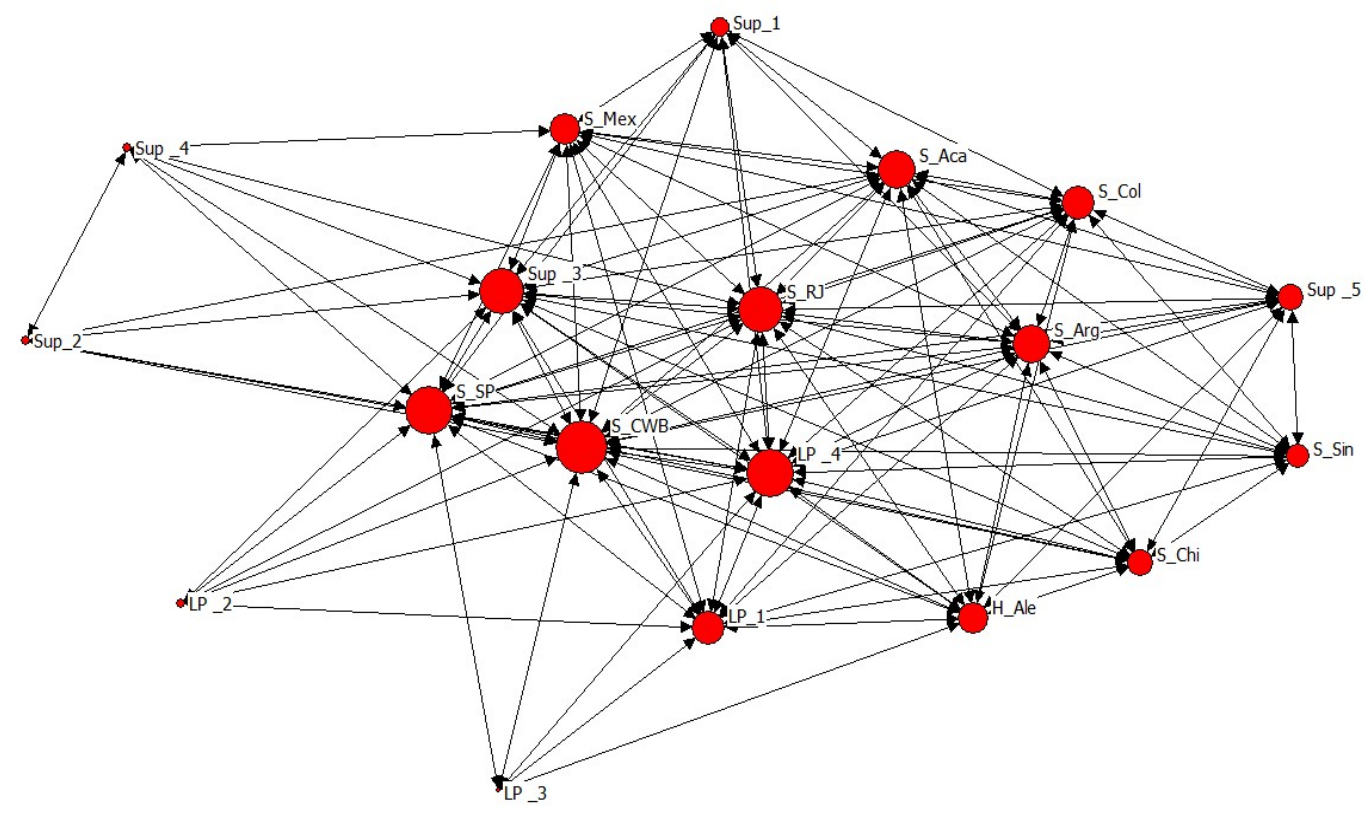

Figure 3. Egocentric Network

Source: Weymer et al., 2017, p.50

The configuration of the network is based on the following properties of centrality obtained from the symmetric network - Degree, Closeness, Betweenness, and Eigenvector-which are measures of normal centrality, in addition to a measure of structural holes (Effsize). They can be visualized in Table 4.

Table 4. Independent variables of the egocentric network

\begin{tabular}{l|lllll}
\hline & \multicolumn{3}{|l}{ Centrality measures } & & Structural holes \\
\hline Organizations & Degree & Closenness & Betweenness & Eigenvector & Effsize \\
S_Arg & 77.78 & 81.82 & 1.02 & 37.71 & 3.00 \\
S_Sin & 55.56 & 69.23 & 24 & 28,29 & 1.80 \\
S_Col & 72.22 & 78.26 &, 79 & 35.50 & 2.69 \\
S_Mex & 66.67 & 75,00 & 1.25 & 32.31 & 3.00 \\
H_Ale & 66.67 & 75,00 & 1.22 & 32.53 & 2.83 \\
S_Chi & 61.11 & 72.00 & 31 & 30.97 & 1.91 \\
S_CWB & 100.00 & 100.00 & 7.54 & 42,41 & 7.44 \\
S_RJ & 88.89 & 90,00 & 3.73 & 40.17 & 5.25
\end{tabular}




\begin{tabular}{l|lllll} 
S_SP & 94.44 & 94.74 & 6.52 & 40.38 & 6.88 \\
S_Aca & 77.78 & 81.82 & 2.01 & 36.52 & 3.86 \\
Sup_1 & 50.00 & 66.67 &, 0 & 26.58 & 1.00 \\
Sup_2 & 33.33 & 60.00 & 22 & 16.62 & 1.67 \\
LP_1 & 72.22 & 78.26 & 2.27 & 33.36 & 4.08 \\
LP_2 & 33.33 & 60.00 &, 0 & 18.22 & 1.00 \\
LP_3 & 27.78 & 58.06 &, 0 & 14.62 & 1.00 \\
Sup_3 & 88.89 & 90,00 & 4.56 & 39.17 & 5.59 \\
Sup_4 & 33.33 & 60.00 & 22 & 16.24 & 1.67 \\
LP_4 & 94.44 & 94.74 & 5.60 & 41.25 & 6.41 \\
Sup_5 & 61.11 & 72.00 & 40 & 30.63 & 2.09 \\
\hline
\end{tabular}

Source: Weymer et al., 2017, p.52

After the standardization of all variables, matrices were processed in UCINET software in order to perform MRQAP. In addition to the five independent variables presented in Table 4, the dimensions of inter-organizational learning (knowledge integration, joint sensemaking, and information sharing) were also considered independent variables and can be represented as shown in Figure. 4.

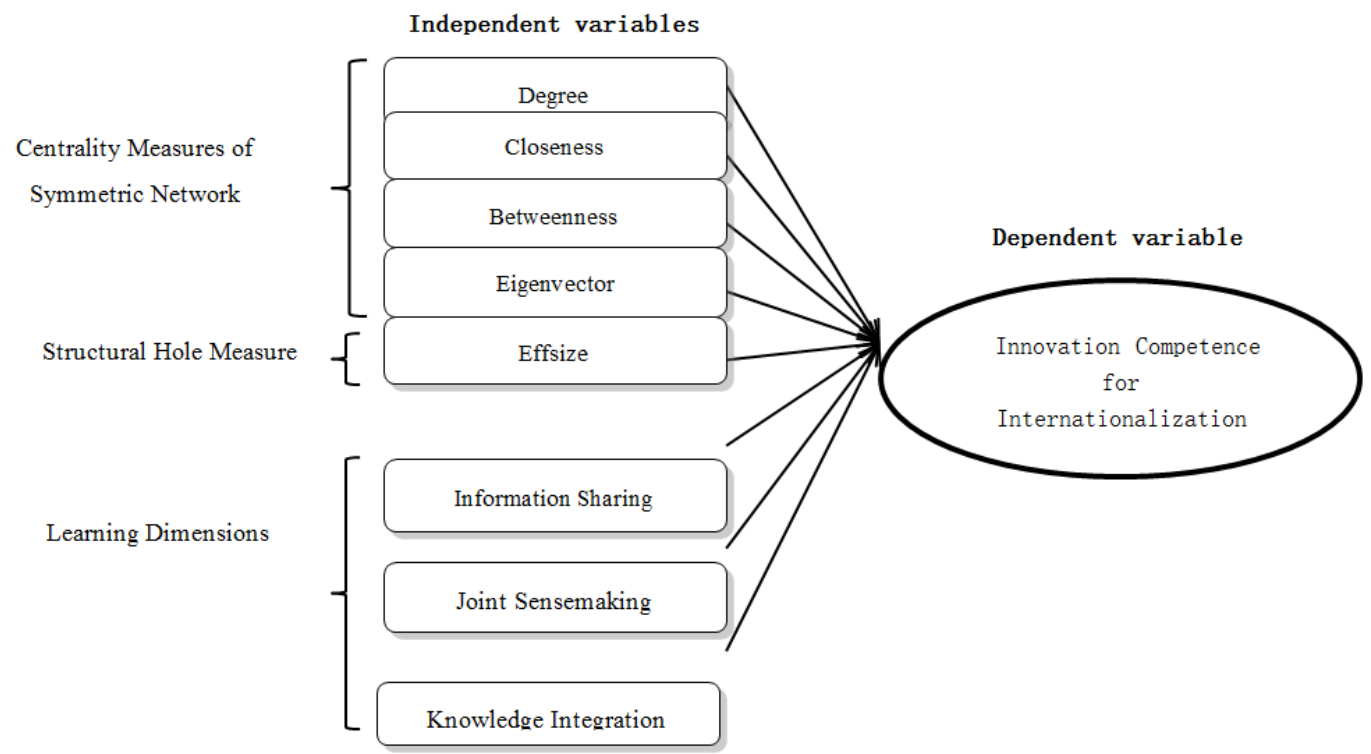

Figure 4. Relationship between independent variables and the dependent variable

The path to multiple regression through UCINET software was as follows: Testing Hypotheses > Dyadic (QAP) > QAP Regression > Double Dekker Semi-Partialling MRQAP. The result is presented in Table 5.

Table 5. Multiple regression results - Value of "P" and adjusted R squared

\begin{tabular}{llllll}
\hline Model Fit & $R$-square $\left(R^{2}\right)$ & Adj R-Sqr (Adjusted $\left.R^{2}\right)$ & $P$-Value & Obs & perms \\
\hline Model & 0068 & 0045 & 0002 & 342,000 & 4000.000 \\
\hline
\end{tabular}

Source: Research data

Regarding the coefficient of determination $\left(\mathrm{R}^{2}\right), 6.8 \%$ of the variance of the dependent variable "innovation competence for internationalization," around its mean, can be explained by the independent variables (or predictors). Comparing the aforementioned coefficient with the adjusted coefficient of determination (adjusted $\mathrm{R}^{2}$ ), a reduction in the explanatory power (4.5\%) is noted, which may be related to the inclusion of independent variables.

However, the value of "P" is determined to justify the analysis of these relationships. Values of "P" less than 0.01 signify a less than $1 \%$ chance that the relationship occurred randomly. In this case, the value of 0.002 can be 
considered very significant, as it signifies more than $99.8 \%$ certainty that the relationship found was not due to chance.

Table 6. Multiple regression via QAP (MRQAP)

\begin{tabular}{l|llllll}
\hline Independent Variables & Un-Stdized & Stdized Coef & P-value & As Large & As Small & Std Err \\
\hline Betweenness & -0.36560 & -0.43811 & 0.21920 & 0.78105 & 0.21920 & 0.51973 \\
Closenness & -0.54015 & -0.52989 & 0.27893 & 0.72132 & 0.27893 & 1.05745 \\
Degree & 1.90387 & 1.91963 & 0.12147 & 0.12147 & 0.87878 & 1.70395 \\
Effsize & 0.03152 & 0.03422 & 0.45289 & 0.45289 & 0.54736 & 0.60676 \\
Eigenvector & -1.16472 & $\underline{-1.28444}$ & 0.09423 & 0.90602 & 0.09423 & 0.94022 \\
Information sharing & -0.03803 & $\underline{-0.29437}$ & 0.01425 & 0.98600 & 0.01425 & 0.01836 \\
Knowledge integration & 0.02635 & $\underline{0.20503}$ & 0.04924 & 0.04924 & 0.95101 & 0.01731 \\
Joint sensemaking & 0.02322 & 0.17648 & 0.10947 & 0.10947 & 0.89078 & 0.01950 \\
Intercept & 0.36698 & 0.00000 & 0.00000 & 0.00000 & 0.00000 & 0.00000 \\
\hline
\end{tabular}

Source: research data

According to Bisquerra, Sarriera, and Martínez (2007, p. 77), "the level of significance is calculated a posteriori, that is, when the result of the significance test is already known." As the analysis of this research takes relationships into account, it was decided to consider 0.10 as an acceptable level of significance, since the strength of the relationships of some variables that would be excluded when considering $\mathrm{p}<0.05$ may offer interesting explanations when using the standardized regression coefficient (the Beta coefficient), because "it allows a direct comparison between coefficients concerning their relative power of explanation of the dependent variable" (HAIR et al., 2009, p. 150).

Although the independent variables "Eigenvector" and "Information sharing" are within the degree of significance, when considering the Beta coefficient, it is noteworthy that both independent variables negatively influence the dependent variable. In other words, the data demonstrate that organizations that relate to other organizations with a greater structural prestige in the network (Eigenvector) may have a negative influence on innovation competence for internationalization, and that information sharing does not contribute positively to globalized innovation. This aspect is important because it reflects on the possibility that organizations with greater structural prestige may have a greater tendency to explore rather than share information.

Based on the information collected from the interview with a manager who has worked for 14 years in the company and who was originally employed by one of the companies of origin, it is possible to suggest that information sharing, although frequent, has become centralized and does not always lead to knowledge integration, because the former does not necessarily happen at the strategic level of discussions. From the perspective of contributing to the institutionalization of global organizational competencies based on local ideas, especially linked to innovation, it seems that such stimulus was very limited after "fusion," in the terms defined by the interviewee.

This limitation does not, however, imply that there is a lack of participation by the subsidiaries. The dynamics of the egocentric network, especially in the relationship between the parent company and subsidiaries, follows the line of thought of Rugman and Verbeke (2001), starting from a structure that allows for an understanding of the specific advantages of subsidiaries in a network perspective, as long as decisions pass through a validation process that is aligned with the organization's global strategies.

Although initiative may initially seem to be a limiting agent, Birkinshaw, Hood, and Jonsson (1998) warn that in some situations, initiative can be considered a subversive stance by the parent company, especially with regard to individualistic behaviors that do not follow global strategic priorities and guidelines.

For the other measures of centrality-degree, closeness, and betweenness-and the measure of structural holes - effsize - the significance level was not within the acceptable limit. Such centrality measures could provide conditions to identify the degree of influence of certain organizations in the network structure through direct, indirect, and proximity relationships, complementing the inference made regarding the Eigenvector variable. Statistically, it is important to remember that the null hypothesis of this research implicitly assumes that these measures of centrality have no influence on the innovation competence for internationalization. 
On the other hand, the variables of joint sensemaking and knowledge integration positively influence the innovation competence for internationalization. The congruence of construction of meaning can be justified by the fact that communication between companies is guided by the need to create joint teams to analyze and discuss both operational and strategic issues, but not necessarily with regard to the development of new products to serve local markets.

In any case, regardless of the mechanism or path to construction of meaning, the fact is that relational learning (Cheung, Myers \& Mentzer, 2011; Hakansson, Snehota, 1995) in the egocentric network allows for the exploration of globally developed innovations (Bartlett \& Ghoshal, 1988); however, there is strong evidence that there are other variables not included in this research that can influence the innovation competence for internationalization in the network.

\section{Conclusion}

This study aimed to evaluate the influence of an egocentric transnational network on the innovation competence for internationalization of a transnational focal organization, which is seen as one of the leading worldwide players in the telecommunications sector. Based on the results, it was possible to identify that the egocentric network in this study is oriented toward innovation, considering the 19 companies that are part of the network of relationships.

It is noteworthy that the approach of the concept of innovation competence for internationalization from a perspective of learning networks is opposed to the concept of competence as an internal resource. Several studies attribute the origin of the competence concept to an article written by Penrose (1959), which suggested that the growth processes of firms are characterized by external and internal opportunities, derived from the firm's set of resources, looking at a characteristic from inside out.

In this perspective, the author seems to have anticipated several concepts of Resource Based Theory and, somehow, offers a starting point for the exploration of other interrelated themes, such as specificities of the companies, the heterogeneity of resources, and the importance of knowledge of these possible resources and their possible applications (Leite \& Porsse, 2005). The concept evolved with a particular focus on Wernerfelt's (1984) work by analyzing firms with a view to their resources rather than focusing on their products. The evolution of the concept gained new dimensions with a study by Barney (1991), which transformed the Resource Based View into a robust theory, opening new perspectives in organizational studies.

In this sense, one of the main contributions of this research was to provide evidence, from an egocentric network with the support of the technique of network analysis and a statistical tool that provided objectivity to the study. Moreover, the traditional conception of organizational competences as an internal resource can be extended to the perspective of relational embeddedness by considering competence for innovation toward internationalization as an inter-organizational level of competence, suggesting the need to explore new studies that will help complement and deepen this research, in addition to the dimensions of learning contemplated in this study.

A limitation of this study is that the ability to explain learning in networks based on the "innovation competence for internationalization" needs to be deepened in order to broaden the development of scientific knowledge on the subject. This evidences the complexity of the studied variables, especially from the perspective of relational embeddedness and innovation in a globalized context.

\section{References}

Andersson, U., Forsgren, M., \& Holm, U. (2002). The strategic impact of external networks: subsidiary performance and competence development in the multinational corporation. Strategic Management Journal, 23, 979-996. https://doi.org/10.1002/smj.267

Babbie, E. (1999). Métodos de pesquisas de survey. Belo Horizonte: UFMG.

Baldi, M., \& Lopes, F. D. (2009). Redes como perspectiva de análise e como estrutura de governança: uma análise das diferentes contribuições. RAP, 43(5), 1007-1035. Retrieved from https://www.scielo.br/pdf/rap/v43n5/v43n5a03.pdf

Bartlett, C. A., \& Ghoshal, S. (1988). Organizing for worldwide effectiveness: the transnational solution. California Management Review, 27(3), 54-74. https://doi.org/10.2307/41166538

Biernacki, P., \& Waldorf, D. (1981). Snowball sampling: problems and techniques of chain referral sampling. Sociological Methods and Research, 10(2), 141-63. Retrieved from https://www.ncjrs.gov/App/Publications/abstract.aspx?ID=146745 
Birkinshaw, J. M., Hood, N., \& Jonsson, S. (1988). Building firm-specific advantages in multinational corporations: the role of subsidiary initiative. Strategic Management Journal, 19(3), 221-241. https://doi.org/10.1002/(SICI)1097-0266(199803)19:3<221::AID-SMJ948>3.0.CO;2-P

Bisquerra. R., Sarriera, J. C., \& Martínez, F. (2004). Introdução à Estatística: enfoque informático com o pacote estatístico SPSS. Porto Alegre: Artmed.

Borgatti, S., Everett, M., \& Freeman. L. (2002). Ucinet for Windows: Software for Social Network Analysis. Harvard Analytic Technologies.

Chetty, S. K., \& Stangl, L. M. (2010). Internationalization and innovation in a network relationship context. European Journal of Marketing, 44(11/12), 1725-1743. https://doi.org/10.1108/03090561011079855

Cheung, M., Myers, M. B., \& Mentzer, J. T. (2011). The value of relational learning in global buyer-supplier exchanges: a dyadic perspective and test of the pie-sharing premise. Strategic Management Journal, 32, 1061-1082. https://doi.org/10.1002/smj.926

Chung, W., \& Yeaple, S. International knowledge sourcing: Evidence from U.S. firms expanding abroad. Strategic Management Journal, 29(11), 1207-1224. https://doi.org/10.1002/smj.706

Dunning, J. H. (1993). Multinational enterprises and the global economy. Workhingan: Addison-Wesley.

Freire, A. C., Baldi, M., \& LOPES, F. D. (2010). Expandindo a análise de redes de inovação: uma reflexão a partir da perspectiva de redes sociais. XXVI Simpósio da Gestão da Inovação Tecnológica, Anpad.

Granovetter M. (1985). Economic action and social structure: the problem of embeddedness. American Journal of Sociology, 91(3), 481-510. Retrieved from http://www.jstor.org/stable/2780199

Granovetter, M. (1973). The strength of weak ties. American Journal of Sociology, 78(6), 1360-1380. https://doi.org/10.1086/225469

Granovetter, M. (1992). Problems of explanation in economic sociology. In Networks and Organizations: Structure, Form and Action, Nohria N, Eccles R(eds). Harvard Business School Press: Boston, MA, 25-56.

Gulati, R. (1988). Alliances and networks. Strategic Management Journal, 19(4), 293-317. https://doi.org/10.1002/(SICI)1097-0266(199804)19:4<293::AID-SMJ982>3.0.CO;2-M.

Hage, J., \& Hollingsworth, J. R. (2000). A strategy for the analysis of idea innovation networks and institutions. Organization Studies, 21(5), 971-1004. https://doi.org/10.1177/0170840600215006

Hair, J. F., Black, W. C., Babin, B. J., Anderson, R. E., \& Tatlam, R. R. (2009). Análise Multivariada de Dados. 6. Ed. Porto Alegre: Bookman.

Hakansson, H., \& Snehota, I. (1995). Developing Relationships in Business Networks. Routledge: London.

Hanneman, R. A. (2001). Introduction to social network methods. 2001. Disponível. Retrieved from http://faculty.ucr.edu/ hanneman/networks/nettext.pdf>. Acesso em: 11 dez. 2016

Hansen, M. T. (1999). The search-transfer problem: the role of weak ties in sharing knowledge across organization subunits. Administrative Science Quarterly, 44, 82-111. https://doi.org/10.2307/2667032

Hillman, A. Editor's comments. (2009). Academy of Management Review, 34(1), 7-10. https://doi.org/10.5465/AMR.2009.35713263

Kanter, R.M. (1989). Swimming in newstreams: Mastering innovation dilemmas. California Management Review, 45-69. https://doi.org/10.2307/4116658

Kueny, C. R., Toomey, E., Pole, D., \& Hinyard. L. (2017). Uniting Saint Louis University's interprofessional education program with organizational learning: A theory-based model to guide IP education and practice. Journal of Interprofessional Education \& Practice, 6, 7-14. https://doi.org/10.1016/j.xjep.2016.11.001

Lawson, B., \& Samson, D. (2001). Developing innovation capability in organisations: a dynamic capabilities approach. International Journal of Innovation Management, 5(3), 377-400. https://doi.org/10.1142/S1363919601000427

Leite, J. B. D., \& Porsse, M. C. S. (2005). Competição baseada em competências e aprendizagem organizacional. In: Os novos horizontes da gestão: Aprendizagem organizacional e competências. Porto Alegre: Bookman.

Leontiades, J. C. (2001). Managing de global enterprises: Competing in the information age. Harlow: Prentice Hall, 45-57. 
Lundvall, B. A. (1985). Product Innovation and User-Producer Interaction. Aalborg: Aalborg Universitetsforlag.

Marins, L. M., \& Zawislak, P. A. (2010). O desempenho inovativo de sete firmas brasileiras à luz de um conjunto de novos indicadores de inovação. Anais do EnANPAD.

Marsden, P. V. (2005). Recent Developments in Network Measurement. In: Carrington, P., Scott, J., \& Wasserman, S. (Orgs.). Models and Methods in Social Network Analysis. New York: Cambridge Press.

Mentzer, J. T., Min, S., \& Zacharia, Z. (2000). The nature of interfirm partnering in supply chain management. Journal of Retailing, 76(4), 549-568. https://doi.org/10.1016/S0022-4359(00)00040-3

Nishijima, M., Ivanauskas, T. M., \& Sarti, F. M. (2017). Evolution and determinants of digital divide in Brazil (2005-2013). Telecommunications Policy, 41(1), 12-24. https://doi.org/10.1016/j.telpol.2016.10.004

Ohmae, K. (2006). Onovo palco da economia global: desafios e oportunidades em um mundo sem fronteiras. Porto Alegre: Bookman.

Penrose, E. T. (1959). The theory of the growth of the firm. London: Basil Blackwell.

Pinho, J. C., \& Prange, C. (2016). The effect of social networks and dynamic internationalization capabilities on international performance. Journal of World Business, 51(3), 391-403. https://doi.org/10.1016/j.jwb.2015.08.001

Rauen, C. V., Hiratuka, C., \& Fracalanza, P. S. (2011). Universalization of telecommunications services: Public policies in the OECD and in Brazil. International Journal of Development Issues, 10(2), 108-122. http://dx.doi.org/10.1108/14468951111149069

Reinert, M., \& Maciel, C. O. (2012). Análise das Díades para Compreender a Semelhança da Ação Estratégica: uma aplicação da Regressão Múltipla QAP (MRQAP). Revista hispana para el análisis de redes sociales, 22(5). Retrieved from http://revista-redes.rediris.es

Rugman, A. M., \& Verbeke, A. (2001). Subsidiary specific advantages in multinational enterprises. Strategic Management Journal, 22(3), 237-250. https://doi.org/10.1002/smj.153

Scott, J. (2000). Social Network Analysis. (2nd ed.). Thousand Oaks, Califórnia: SAGE Publications.

Selnes, F., \& Sallis, J. (2003). Promoting relationship learning. Journal of Marketing, 67, 80-95. https://doi.org/10.1509/jmkg.67.3.80.18656

Symeou, P. C. (2011). Economy size and performance: An efficiency analysis in the telecommunications sector. Telecommunications Policy, 35(5), 426-440. https://doi.org/10.1016/j.telpol.2011.03.008

Uzzi, B. (1996). The sources and consequences of embeddedness for the economic performance of organizations: the network effect. American Sociological Review, 61, 674-698. Retrieved from https://www.jstor.org/stable/2096399

Veiga, C. R. P., Veiga, C. P., Corso, J. M., \& Silva, W. V. (2016). Vaccine R\&D in Brazil: The effectiveness of push and pull regulations. World Patent Information, 46, 11-18. https://doi.org/10.1016/j.wpi.2016.05.006

Wasserman, S., \& Faust, K. (1994). Social network analysis: methods and applications. New York: Cambridge University Press.

Weymer, A. S. Q., Kato, H., Veiga, C. P., \& Moreira, V. R. The relationship structure of a transnational, ego-centered, and innovation-oriented network. Asian Social Science, 13(5), 45-56. https://doi.org/10.5539/ass.v13n5p45

Wu, J., Wang, C., Hong, J., Piperopoulos, P., \& Zhuo, S. (2016). Internationalization and inno vation performance of emerging market enterprises: The role of host-country institutional development. Journal of World Business, 51(2), 251-263. https://doi.org/10.1016/j.jwb.2015.09.002

\section{Copyrights}

Copyright for this article is retained by the author(s), with first publication rights granted to the journal.

This is an open-access article distributed under the terms and conditions of the Creative Commons Attribution license (http://creativecommons.org/licenses/by/4.0/). 